\title{
Bat predation by the Dominica Boa (Boa nebulosa)
}

\section{Baptiste Angin}

Ardops Environnement, Pointe Allegre, 97115 Sainte Rose, Guadeloupe. ardops.environnement@gmail.com

Date of publication: 2 October 2014

Citation: Angin, B. (2014) Bat predation by the Dominica Boa (Boa nebulosa). Caribbean Herpetology 51:1-2.

Predation on bats by species of the family Boidae is well known, and a compilation of reported cases was published by Esbérard \& Vrcibradic (2007). In the West Indies, the most frequently documented instances of bat predation have involved Epicrates inornatus in Puerto Rico (Rodriguez \& Reagan 1984, Rodriguez-Duran 1996), which waits at the mouth of a cave for bats to emerge. In the Lesser Antilles, the only reported case of snake predation on bats was for the Saint Lucia Boa (Boa orophias), which preyed on resting bats (Arendt \& Anthony 1986). In this note, I report the first observation of a Dominica Boa (Boa nebulosa) preying on bats while using a strategy similar to that described for Epicrates inornatus.

On 17 June 2014, I waited for the emergence of bats at Stinking Hole in Dominica (15.349 N, 61.341 W). This cave is a roost for three species of bats: Antillean Long-tongued Bat (Monophyllus plethodon), the Gray Funnel-eared Bat (Natalus stramineus), and the Gray Antillean Fruit-eating Bat (Brachyphylla cavernarum) (Genoways et al. 2001). Emergence began at dusk and lasted two hours, during which more than 65,000 bats left the cave (Corso 2008). At 16:00 h, we observed a Dominica Boa measuring about $3 \mathrm{~m}$ in total length near the wall of the cave. When emergence began at 18:34 h, the boa was hanging on an aerial root (Fig. $1 \mathrm{~A}$ ). About $50 \mathrm{~cm}$ of its body, including its head, was perpendicular to the tail as it tried to catch bats passing through the mouth of the cave.

The boa caught a bat, later identified as Brachyphylla cavernarum, and constricted the prey with the middle of its body while trying simultaneously to catch other bats. When the rate of emergence decreased, the boa initiated ingestion, which lasted 19 min (Fig. 1B). This observation occurred at the end of the fieldwork, so I was unable to determine if other snakes prey on bats at this cave or if this these snakes specialize in bat capture.

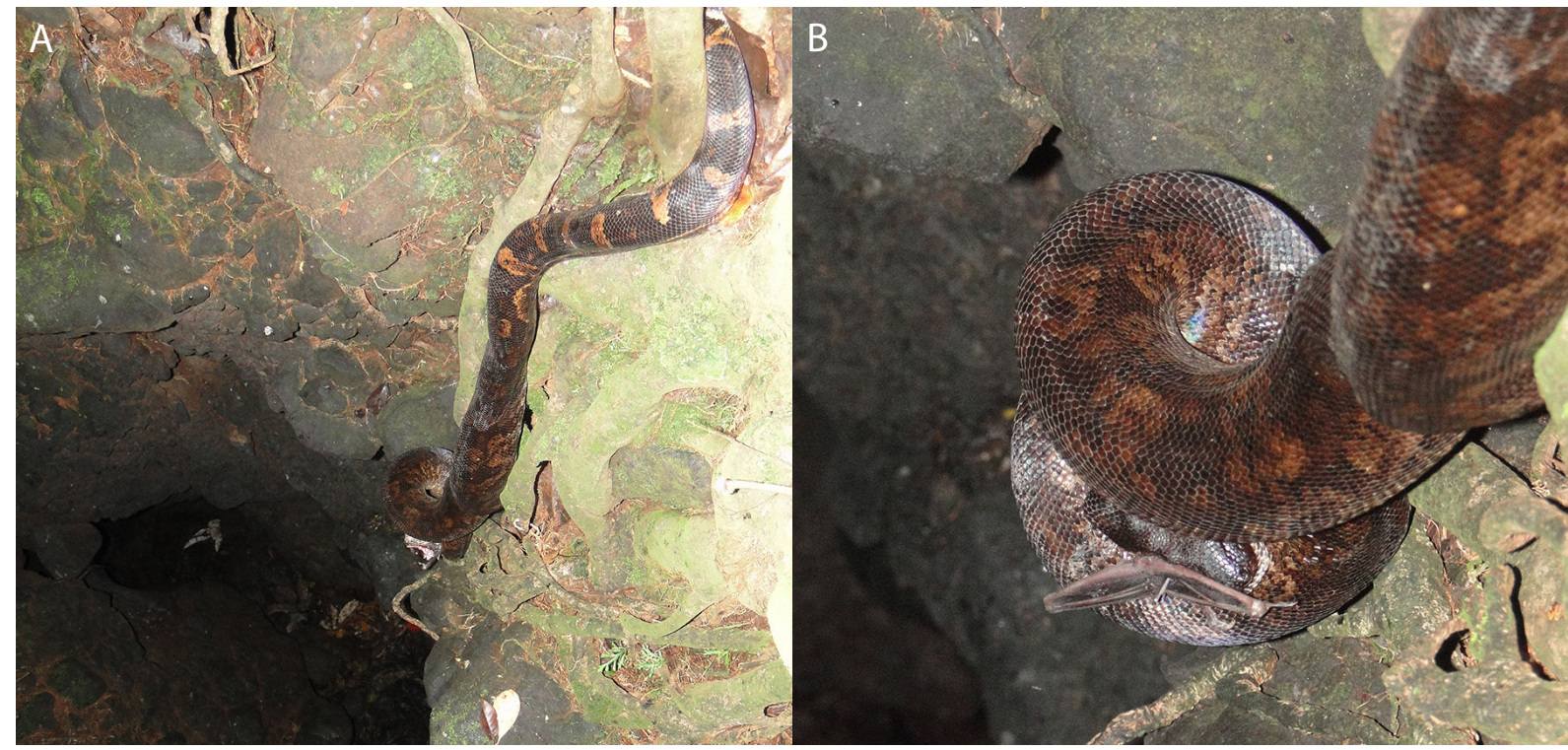

Figure 1. Boa nebulosa (A) hanging on an aerial root, and (B) constricting a bat (Brachyphylla cavernarum) that it just captured. 


\section{Acknowledgements}

We thank Beatrice Ibéné and Régis Gomes from ASFA (Association pour la Sauvegarde de la Faune des Antilles) for information about Stinking Hole Cave, and Charlotte Dromard and Jonathan Pratt for their review. Financial support for our fieldwork was provided by the BIVAAG Program established by the CNRS with support from a European PO-FEDER grant 2007-2013 n²/2.4/-33456, the Guadeloupe Regional Council, the DEAL of Guadeloupe, and the DAC of Guadeloupe.

\section{References}

Arendt W.J., \& Anthony D. (1986) Bat predation by the St. Lucia boa (Boa constrictor orophias). Caribbean Journal of Science, 22, 219-220.

Corso M. (2008) Population Estimate of the Chiropteran Emergence at Stinking Hole, Dominica. Texas A\&M University, 18p.

Esbérard C.E.L., \& Vrcibradic D. (2007) Snakes preying on bats, new records from Brazil and a review of recorded cases in the Neotropical Region. Revista Brasileira de Zoologia, 24, 848-853.

Genoways H.H., Timm R.M, Baker R.J., Philips C.J., \& Schlitter D.A. (2001) Bats of the West Indian Island of Dominica: Natural History Aerography, and Trophic Structure. Special Publications of the Museum of Texas Tech University, 43.

Rodriguez G., \& Reagan D.P. (1984) Bat predation by the Puerto Rican boa (Epicrates inornatus). Copeia, 1984, 219220.

Rodriguez-Duran A. (1996) Foraging ecology of the Puerto Rican boa (Epicrates inornatus): bat predation, carrion feeding and piracy. Journal of Herpetology, 30, 533-536. 